\title{
THE INFLUENCE OF EMOTIONAL INTELLIGENCE ON ORGANIZATIONAL COMMITMENT AND ORGANIZATIONAL CITIZENSHIP BEHAVIOR.
}

\author{
Janis Maria Antony \\ M.Phil. Research Scholar \& Research Assistant: ICSSR Project, Dept. Of Psychology, PSG College of Arts \& \\ Science, Coimbatore- 641 014, Tamil Nadu, India.
}

\section{Abstract}

Over the past few decades there has been tremendous growth in Emotional Intelligence research. It has been learned that since Emotional Intelligence is not a trait, appropriate intervention programmes can inculcate a combination of dynamic skills required for the same. Emotional Intelligence is an essential factor to be considered in an organizational setup. The present study attempts to determine the influence of Emotional Intelligence on Organizational Commitment and Organizational Citizenship Behavior. Commitment and Citizenship behavior are vital aspects of the organizational world.

This study makes use of a sample of 115 Executives working at FCI OEN Connectors, Cochin, Kerala. The tools used for the study are Emotional Intelligence Inventory, The Organizational Commitment Questionnaire and The Organizational Citizenship Behavior Scale. The statistics used for the study are standard deviation and Pearson's product moment correlation. The results indicate that a positive relationship existed between Emotional Intelligence, Organizational Commitment and Organizational Citizenship Behavior.

\section{INTRODUCTION:}

Researchers observed that emotions always work together with cognition and motivation to help the person act appropriately in relation to the social context, or self-regulate. An acceptable definition of emotion is that it is an organized mental response to an event that includes physiological, experiential, and cognitive aspects among others, for which context of relationship, within which expression of emotional intelligence takes place, is important (Lazarus, 1991). Mayer and Salovey (1997) have defined emotional intelligence as "the ability to regulate emotions and intellectual growth." The domain concepts of emotional intelligence originally propounded by Goleman (1998) have influenced the definition given by Salovey and Mayer. Goleman defines emotional intelligence as, "the capacity for recognizing our own feelings and those of others, for motivating ourselves, and for managing emotions well in ourselves and in our relationships. Furthermore, he suggested that El consisted of five general components viz. self-awareness, self-regulation, motivation, empathy, and social skills.

Organizational Commitment is one of the most frequently studied concepts in industrial/organizational psychology and organizational behavior. It has been shown by the studies that organizational commitment has the potential to predict a variety of organizational outcomes, such as increased job performance, reduced turnover and withdrawal cognitions, lower absenteeism rate, and increased organizational citizenship behavior (Mathieu \& Zajac, 1990: Meyer \& Allen, 1997: Meyer, Stanley, Herscovitch, \& Topolnytsky, 2002: Sinha \& Jain, 2004). Moreover, committed employees who are highly motivated to contribute their time and energy to the pursuit of organizational goals are increasingly acknowledged as the primary asset available to an organization (Pfeffer, 1998).

Behaviors that exceed delineated role expectations but are important and even crucial for an organization's survival are defined as organizational citizenship behaviors (OCB) (e.g. Brief \& Motowildo, 1986: George, 1990; Katz \& Kahn, 1966). The behaviors were first so named by Organ and his colleagues (Bateman \& Organ, 1983: Organ, 1988) in describing Katz's (1964) category of extra-role behaviors. These are behaviors that help the organization but may not be directly or explicitly recognized in the organization's formal reward system (Podsakoff, MacKenzie, Paine, \& Bachrach, 2000). Organ (1988) defines Organizational Citizenship Behavior (OCB) as "individual behavior that is discretionary, not directly or explicitly recognized by the formal reward system and that in the aggregate promotes the effective functioning of the organization." These have also been identified as prosocial organizational behaviors (Brief \& Motowildo, 1986), organizational spontaneity and civic organizational behavior (Borman \& Motowildo, 1993).

A study on Psychological Empowerment and Organizational Citizenship Behavior in IT Manager's was conducted by Jyotsna Bhatnagar and Sheetal Sandhu (2005), to identify the strength of relationship among the two variables on IT sector in India. Results indicate that managers who perceive psychological empowerment in their occupational environment exhibit organizational citizenship behavior.

Meera Shanker and Omer Bin Sayeed (2006) formulated a paper on "Assessing Emotionally Intelligent Managers: Development of an Inventory and relationship with managers' professional development". The findings suggest that emotionally intelligent managers are most valued human resources for the organization as they extensively contribute to organization's capability and resourcefulness.

The study on "Organizational Commitment and its determinants" by Madan Pal Sharma (2006) was designed to find out the situational and personal determinants of organizational commitment. Results indicated that both situational and personal factors contribute to workers commitment to organization. Between the two, situational factors contribute more to commitment than do person-related factors.

The study on "Assessing the relationship between emotional intelligence, occupational self-efficacy and organizational commitment" was conducted by Neerpal Rathi and Renu Rastogi (2009. The research implies that El and 
occupational self-efficacy are related with a variety of organizationally desirable outcomes. Therefore an understanding of the levels of El and occupational self-efficacy will be helpful in taking suitable steps to enhance these competencies among the employees.

A study on "Perceived Organizational Support, Work Motivation and Organizational Commitment as determinants of Job Performance" was done by C.R Darolia, Parveen Kumari and Shashi Darolia (2010. The result was that there was a modest level of positive correlation between POS, WM and OC and their significant contribution in determining job performance.

\section{AIMS}

To assess the level of emotional intelligence among executives.

To assess the level of commitment towards the organization by the executives.

To assess the extent to which executives possess organizational citizenship behavior.

To assess the impact of emotional intelligence on organizational commitment and organizational citizenship behavior.

\section{METHODOLOGY}

The sample was selected using purposive sampling technique. The sample consisted of 115 executives working at $\mathrm{FCl}$ OEN Connectors Ltd., Cochin. The tools used for the study were:

Emotional Intelligence Inventory developed by Meera Shanker and Omer Bin Sayeed, 2006.

The Organizational Commitment Questionnaire developed by Mowday et.al.,1979.

The Organizational Citizenship Behavior Scale developed by Biswajeet Pattanayak, Rajnish Kumar Misra and Phalgu Niranjana, 2003.

The questionnaires were given to the respondents with appropriate instructions and the data was scored as per the set norms. The results were then tabulated, discussed and conclusions were drawn thereafter.

RESULTS

TABLE NO.1 shows the mean and standard deviation of Emotional Intelligence, Organizational Commitment and Organizational Citizenship Behavior.

\begin{tabular}{|l|l|l|l|}
\hline S.NO. & \multicolumn{1}{|c|}{ VARIABLES } & \multicolumn{1}{|c|}{ S D } \\
\hline 1. & Emotional Intelligence & 319.3 & 40.12 \\
2. & Organizational Commitment & 59.5 & 10.38 \\
3. & Organizational Citizenship Behavior & 174.5 & 23.26 \\
\end{tabular}

TABLE NO.2 shows the correlation ( $r$ ) of Emotional Intelligence with Organizational Commitment and Organizational Citizenship Behavior.

\begin{tabular}{|l|l|l|l|}
\hline S.NO. & VARIABLES CORRELATION $(r)$ & $\begin{array}{l}\text { LEVEL } \\
\text { SIGNIFICANCE }\end{array}$ \\
\hline 1. & $\begin{array}{l}\text { Emotional Intelligence and Organizational } \\
\text { Commitment }\end{array}$ & 0.39 & 0.05 \\
\hline 2. & $\begin{array}{l}\text { Emotional Intelligence and Organizational } \\
\text { Citizenship Behavior }\end{array}$ & 0.470 & 0.05 \\
\hline
\end{tabular}

\section{DISCUSSION}

Table no.1 showing the mean and standard deviation of Emotional Intelligence, Organizational Commitment and Organizational Citizenship Behavior signifies that all the three variables are average in the executives with mean scores of 319.3, 59.5 and 174.5 respectively. This shows that the executives on a moderate basis can manage their emotions and maintain inter personal relationships. They are also committed to their organization and perform extra-roles for the benefit of their organization on an average basis.

Table no.2 showing the correlation of Emotional Intelligence with Organizational Commitment and Organizational Citizenship Behavior portrays that a positive correlation exists between Emotional Intelligence and Organizational Commitment as well as Emotional Intelligence and Organizational Citizenship Behavior, the scores being 0.39 and 0.470 
respectively. Thus, higher the level of emotional intelligence within an individual, greater will be his commitment towards the organization and his citizenship behavior.

\section{CONCLUSION}

This study aims to find out the influence of Emotional Intelligence Organizational Commitment and Organizational Citizenship Behavior. The study was done on executives and purposive sampling technique was adopted for the same. The tools used for the study are Emotional Intelligence Inventory, The Organizational Commitment Questionnaire and The Organizational Citizenship Behavior Scale. The following conclusions were made as a result of the study:

The executives possess average level of Emotional Intelligence, Organizational Commitment and Organizational Citizenship Behavior.

A positive correlation existed between Emotional Intelligence and Organizational Commitment as well as Emotional Intelligence and Organizational Citizenship Behavior.

It is thus learned that Emotional Intelligence is required to be possessed at least to a moderate level for better commitment towards one's organization and also to perform extra role behaviors. The study cannot be however generalized because the sample was chosen only from a particular organization. Further research could be done in this for better reliability and validity.

\section{REFERENCES}

[1] Bateman, T.S., and Organ, D.W.(1983), "Job satisfaction and good soldier relationship between affect and employee citizenship”, Academy of Management Journal, 26, 587-595.

[2] Bhatnagar.Jyotsna, and Sandhu.Sheetal (2005) "Psychological empowerment and organizational citizenship behavior in IT managers: a talent retention tool". Indian Journal of Industrial Relations, Vol.40, No.4.

[3] Borman, W.C., and Motowildo, S.J(1993), "Expanding the criterion domain to include elements of contextual performance", In N. Schmitt, W.C. Borman, and Associates(Eds), Personnel selection in organization, (pp.71-98), San Francisco: Jossey-Bass.

[4] Brief, A.P., and Motowildo, S.J.(1986), "Prosocial organizational behaviors", Academy of Management Review, 11, 710-725.

[5] Darolia.C.R, Kumari Parveen and Darolia Shashi (2010) "Perceived organizational support, work motivation and organizational commitment as determinants of job performance". Journal of the Indian Academy of Applied Psychology, Vol.36, No.1.

[6] George, J.M.(1990), "Personality affect and Behavior in groups", Journal of personality and Social Psychology, 75, 462474.

[7] Goleman, D. (1998), Working with Emotional Intelligence", Bantam Books, New York.

[8] Katz, D., and Kahn, R.L., (1966), "The social psychology of Organization", Wiley, New York.

[9] Lazarus, R. (1991), Emotion and Adaptation, Oxford University Press, New York.

[10] Mathieu, J.E., and Zajac, D.M., (1990). A review and meta analysis of the antecedents, correlates and consequences of organizational commitment. Psychological Bulletin, 108, 171-194.

[11] Mayer, J.D., and Salovey,P. (1997), "What is Emotional Intelligence" In P.S.D. Sluyter (Ed. ), Emotional development and Emotional Intelligence: Implications for Educators, (pp.3-31), Basic Books, New York.

[12] Meyer, J.P., and Allen, N.J., (1997). Commitment in the workplace: theory, research and application. Thousand Oaks: sage Publications.

[13] Meyer,J.P., Stanley,D.J., Herscovitch,L., and Toplnytsky,L.,(2002). Affective, continuance and normative commitment to the organization: A meta analysis of antecedents, correlates and consequences. Journal of Vocational behavior, 61, 2052 .

[14] Organ, D.W., (1988) “Organizational Citizenship Behavior: the good soldier syndrome”, Lexington, MA: Lexington, 21.

[15] Pfeffer, J. (1998). The human equation. Boston: Harvard Business School Press.

[16] Podsakoff, P.M., MacKenzie, S.B., Paine, JB, and Bachrach, D.G.,(2000), "Organizational citizenship behaviors: A critical review of the theoretical and empirical literature and suggestions for future research", Journal of Management, 26, 513-563.

[17] Rathi.Neerpal and Rastogi. Renu (2009) "Assessing the relationship between emotional intelligence, occupational self efficacy and organizational commitment". Journal of the Indian Academy of Applied Psychology, Vol.35, Special Issue, 93102.

[18]m Shanker. Meera and Sayeed. Omer Bin (2006) "Assessing emotionally intelligent managers: development of an inventory and relationship with manager's professional development”. Indian Journal of Industrial Relations, Vol.42, No.2. 
[19] Sharma. Madan Pal (2006) "Organizational commitment and its determinants". Indian Journal of Industrial Relations, Vol.43, No.3.

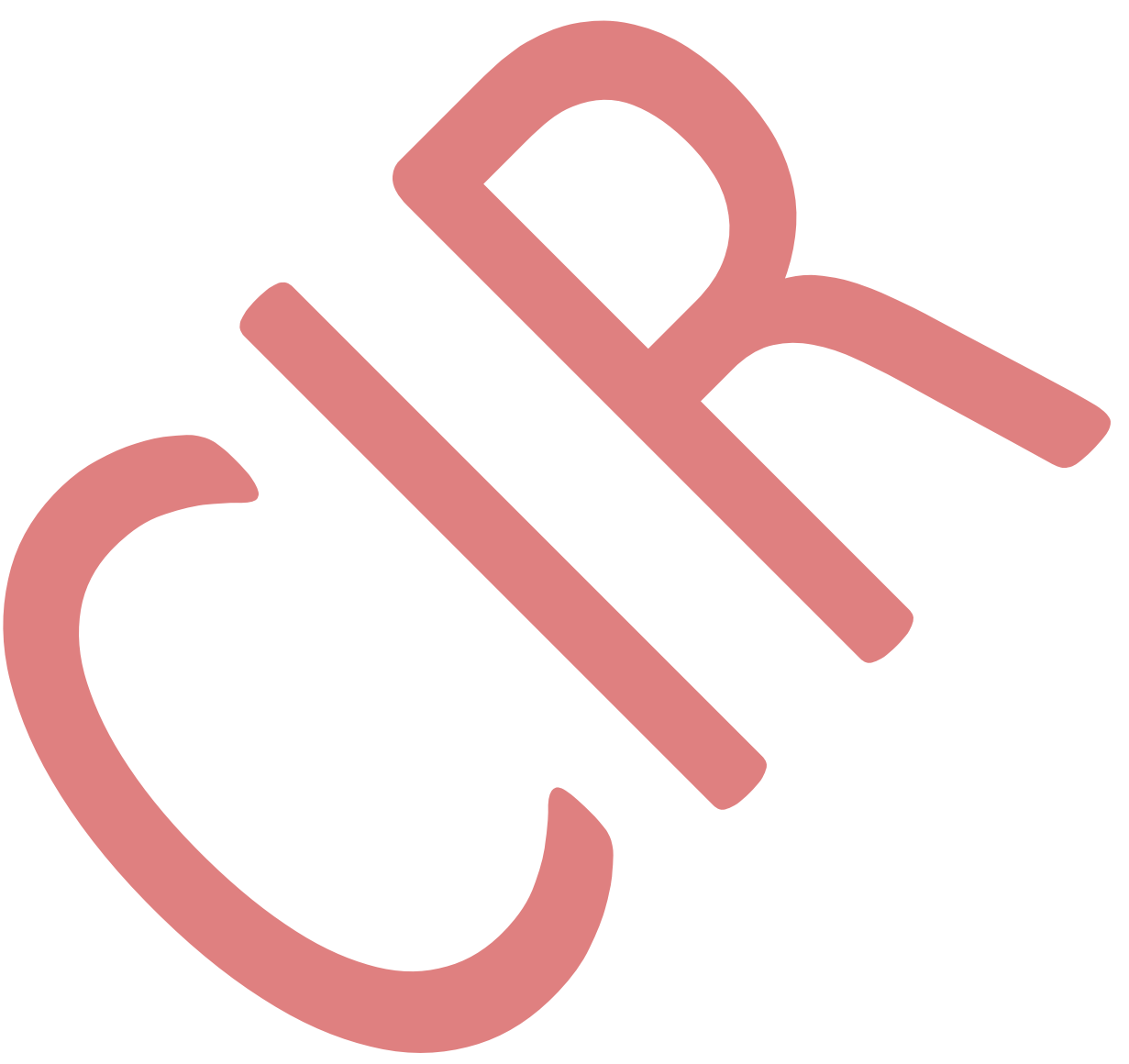

